\title{
Energy
}

Economics

\section{Energy consumption and GDP: causality relationship in G-7 countries and emerging markets}

\author{
Ugur Soytas ${ }^{\mathrm{a}, *}$, Ramazan Sari ${ }^{\mathrm{b}}$ \\ ${ }^{a}$ Middle East Technical University, Department of Business Administration, Ankara, Turkey 06531 \\ ${ }^{\mathrm{b}}$ Abant Izzet Baysal University, Department of Economics, Bolu, Turkey 14280
}

\begin{abstract}
The causality relationship between energy consumption and income is a well-studied topic in energy economics. This paper studies the time series properties of energy consumption and GDP and reexamines the causality relationship between the two series in the top 10 emerging markets - excluding China due to lack of data-and G-7 countries. We discover bi-directional causality in Argentina, causality running from GDP to energy consumption in Italy and Korea, and from energy consumption to GDP in Turkey, France, Germany and Japan. Hence, energy conservation may harm economic growth in the last four countries. (c) 2002 Elsevier Science B.V. All rights reserved.
\end{abstract}

Keywords: Energy consumption; Economic growth; Cointegration; Vector error correction

JEL classification: $\mathrm{Q} 43$

\section{Introduction}

The causal relationship between energy consumption and income is a well-studied topic in the literature of energy economics. The causality is in the sense of Granger causality (Granger, 1969). Kraft and Kraft (1978), in their pioneering study, found unidirectional causality running from GNP to energy consumption for the United States. They utilized the technique of Sims (1972) and used annual data for the 1947-1974 period. However, Akarca and Long (1980) pointed out that the

\footnotetext{
* Corresponding author. Tel.: +90-312-210-2010; fax: +90-312-210-1243.

E-mail address: soytas@ba.metu.edu.tr (U. Soytas).
} 
Kraft-Kraft results are spurious by changing the time period by 2 years. Other studies utilizing different time periods and different techniques have either confirmed or contradicted Kraft-Kraft results (Abosedra and Baghestani, 1989; Yu and Choi, 1985; Cheng, 1995; Hwang and Gum, 1991; Erol and Yu, 1987).

The large number of studies in this area, unfortunately, found different results for different countries as well as for different time periods within the same country. In most recent studies, researchers have focused on the cointegrating relationship between energy consumption and income for a few countries (e.g. Yu and Jin, 1992; Masih and Masih, 1996, 1997; Glasure and Lee, 1997).

This paper reexamines the causal relationship between GDP and energy consumption in the top 10 emerging markets and the G-7 countries, using cointegration and vector error correction techniques. We use annual energy consumption (EC hereafter) and GDP per capita data. EC is a million metric tons of coal equivalent and is sourced from various issues of United Nation's Statistical Yearbook. GDP per capita data is from Penn World Tables. For all countries, the time period used is 1950-1992, except for: Argentina (1950-1990); Indonesia (1960-1992); Korea (1953-1991); and Poland (1965-1994). Note that we dropped China from the analysis because its energy consumption data was combined with Taiwan for a long period of time and the remaining data was not long enough. All variables used are in natural logarithms. We find evidence of a causal relationship in three of the nine emerging markets and four of the seven developed countries.

\section{Methodology and results}

As a first step of our analyses we checked for unit roots because: (1) Stock and Watson (1989) argue that the causality tests are very sensitive to the stationarity of the series; and (2) Nelson and Plosser (1982) state the fact that many macroeconomic series are non-stationary. We used: Dickey-Fuller (DF); augmented Dickey-Fuller (ADF); and Phillips-Perron (PP) tests to assess the degree of integration of the two series (Dickey and Fuller, 1979; Phillips and Perron, 1988). If the series are non-stationary in levels and stationary when first differenced, then they are said to be integrated of order one. We can test for cointegration between series integrated of the same order. ${ }^{1}$

The results of the DF, PP and ADF unit root tests for levels and first differences show that in all countries, LEC and LGDP appear to be I(1) variables. Among the top 10 emerging markets, only in the case of Indonesia, the ADF test indicates non-existence of a unit root in levels when we assume trend and intercept in the series. However, the test statistics are on the margin and the trend term did not appear significant in the ADF regression. We make similar assumptions for LGDP

\footnotetext{
${ }^{1}$ We do not discuss the methodology in detail since all techniques used in the paper are standard. See Enders (1995) and Greene (1997) for an overview.
} 
in UK and West Germany and for LEC in Italy. Therefore, we conclude that LEC and LGDP are I(1) in all 16 countries.

In the next step, we utilized Johansen (1988) and Johansen and Juselius (1990) maximum likelihood procedure to test for cointegration. The same methodology also provides estimates of the cointegrating vectors. The existence of cointegration rules out Granger non-causality. The results provide evidence of a cointegrating vector for only seven out of 16 countries: Argentina; Turkey; Korea; France; Italy; West Germany; and Japan.

Cointegration implies the existence of Granger causality, however, it does not point out the direction of the causality relationship. Therefore, we employed the vector error correction modeling to detect the direction of the causality. Engle and Granger (1987) argued that if there is cointegration between the series, then the vector error-correction model can be written as:

$$
\Delta \operatorname{LGDP}_{\mathrm{t}}=\Psi_{10}+\sum_{\mathrm{i}=1}^{5} \Psi_{11 \mathrm{i}} \Delta \mathrm{LGDP}_{\mathrm{t}-1}+\sum_{\mathrm{i}=1}^{5} \Psi_{12 \mathrm{i}} \Delta \mathrm{LEC}_{\mathrm{t}-1}+\gamma \mathrm{ECT}_{\mathrm{t}-1}+\eta_{1 \mathrm{t}}
$$

$$
\Delta \mathrm{LEC}_{\mathrm{t}}=\Psi_{10}+\sum_{\mathrm{i}=1}^{5} \Psi_{11 \mathrm{i}} \Delta \mathrm{LEC}_{\mathrm{t}-1}+\sum_{\mathrm{i}=1}^{5} \Psi_{12 \mathrm{i}} \Delta \mathrm{LGDP}_{\mathrm{t}-1}+\gamma \mathrm{ECT}_{\mathrm{t}-1}+\eta_{1 \mathrm{t}}
$$

Where the error correction term (ECT) represents the error terms derived from the long run cointegrating relationship. The error-correction representation allows for causality to emerge via two avenues. First, testing the joint significance of the coefficients $\left(\Psi_{11 \mathrm{i}}\right)$ of the independent variable we can check for short run causality. The joint significance of ' $\Psi_{11 \mathrm{i}}$ ' indicates that the dependent variable is responding to short-term shocks to the stochastic environment. Secondly, the long run causality can be tested by looking at the significance of the speed of adjustment $(\gamma)$, which is the coefficient of the error correction term. The significance of ' $\gamma$ ' indicates that the long run equilibrium relationship is directly driving the dependent variable. In addition to the extra way for causality to emerge, the VEC offers another advantage that the lost information due to differencing is brought back into the system through the error correction term.

The results found evidence of long run uni-directional causality running from LEC to LGDP for Turkey, France, West Germany and Japan. The long run causality is reversed for Italy and Korea, and there is bi-directional long run causality in Argentina. In addition, there is evidence of short run bi-directional causality in Argentina. The bi-directional relationship also holds for Turkey in the short run. In none of the other countries do LGDP and LEC enter significantly in each other's equation, implying lack of short run causality

The causality tests are valid only within the sample period. We utilize variance decompositions (VDCs) in order to assess the validity of causality beyond the sample period. The variance of the forecast error of a variable can be partitioned (in this case into two) with respect to the innovations in each variable in the system. For example, the variance of the forecast error in GDP can be attributable 
to innovations in energy consumption as well as to its own innovations. In that sense, the VDCs can be viewed as out of sample causality tests.

The VDC results are consistent with our findings in VEC model analysis. In the case of Italy, LEC does not appear to explain more than $1.55 \%$ of an innovation in LGDP even after 30 years. In Argentina's case, the portion explained by LEC goes up to $9.08 \%$ from $0 \%$ in 4 years and stabilizes at approximately $7.5 \%$ after 5 years. The LEC in Turkey and Germany accounts for $61-63 \%$ of the shock in LGDP in 30 years. The proportions explained by LEC increase to $90-91 \%$ in France and Japan, thus, indicating causality running from energy consumption to income for Turkey, France, Germany and Japan.

In Argentina and Italy, LGDP accounts for 42 and $31 \%$ of the innovation in LEC after 30 years, respectively. In the case of Korea, the portion of a shock in LEC explained by LGDP fluctuates between 5 and $10 \%$. The results of VDCs may be viewed as an indication of causality running from LGDP to LEC in these countries. Hence, we conclude that, overall, VDCs confirm our findings in VEC model analysis. ${ }^{2}$

\section{Concluding remarks}

In this paper we reexamined the causal relationship between GDP and energy consumption in 16 countries. In all countries, both series appear to be non-stationary in levels, but stationary in first differences. For seven countries, there exists a stationary linear cointegrating relationship between the variables. In Turkey, France, Germany and Japan, the causality runs from energy consumption to GDP. We discovered bi-directional causality in the case of Argentina. This indicates that in the long run energy conservation may harm economic growth in these countries. The causality relationship appears to be reversed for Italy and Korea. The results of VDCs support the causal relationships we discovered using the VEC model.

\section{References}

Abosedra, S., Baghestani, H., 1989. New evidence on the causal relationship between U.S. energy consumption and gross national product. J. Energy Development 14, 285-292.

Akarca, A.T., Long, T.V., 1980. On the relationship between energy and GNP: a reexamination. J. Energy Development 5, 326-331.

Cheng, B.S., 1995. An investigation of cointegration and causality between energy consumption and economic growth. J. Energy Development 21, 73-84.

Dickey, D., Fuller, W., 1979. Distribution of the estimators for autoregressive time series with a unit root. J. Am. Stat. Assoc. 74, 427-431.

Enders, W., 1995. Applied Econometric Time Series. Wiley, New York.

Engle, R.F., Granger, C.W.J., 1987. Co-integration and error correction: representation, estimation and testing. Econometrica 55, 251-276.

\footnotetext{
${ }^{2}$ Full results are not reported in order to conserve space. All statistical results are available from the authors upon request.
} 
Erol, U., Yu, E.S.H., 1987. On the causal relationship between energy and income for industrialized countries. J. Energy Development 13, 113-122.

Glasure, Y.U., Lee, A.R., 1997. Cointegration, error correction and the relationship between GDP and energy: the case of South Korea and Singapore. Resour. Energy Economics 20, 17-25.

Granger, C.W.J., 1969. Investigating causal relations by econometric models and cross-spectral methods. Econometrica 37, 424-438.

Greene, W.H., 1997. Econometric Analysis. Prentice Hall, New Jersey.

Hwang, D., Gum, B., 1991. The causal relationship between energy and GNP: the case of Taiwan. J. Energy Development 16, 219-226.

Johansen, S., 1988. Statistical analysis of cointegrating vectors. J. Econ. Dynamics Control 12, 231-254.

Johansen, S., Juselius, K., 1990. Maximum likelihood estimation and inference on cointegration-with applications to the demand for money. Oxf. Bull. Economics Statistics 52, 169-210.

Kraft, J., Kraft, A., 1978. On the relationship between energy and GNP. J. Energy Development 3, 401-403.

Masih, A.M.M., Masih, R., 1996. Energy consumption, real income and temporal causality: results from a multi-country study based on cointegration and error-correction modeling techniques. Energy Economics 18, 165-183.

Masih, A.M.M., Masih, R., 1997. On the temporal causal relationship between energy consumption, real income and prices: some new evidence from Asian-energy dependent NICs based on a multivariate cointegration/vector error-correction approach. J. Policy Modeling 19, 417-440.

Nelson, C.R., Plosser, C.I., 1982. Trends and random walks in macroeconomic time series. J. Monetary Economics 10, 139-162.

Phillips, P.C.B., Perron, P., 1988. Testing for unit root in time series regression. Biometrica 75, 335-346.

Sims, C.A., 1972. Money, income and causality. Am. Econ. Rev. 62, 540-552.

Stock, J.H., Watson, M.W., 1989. Interpreting the evidence on money-income causality. J. Econometrics 40, 161-182.

Yu, S.H., Jin, J.C., 1992. Cointegration tests of energy consumption, income and employment. Resources Energy 14, 259-266.

Yu, S.H., Choi, J.Y., 1985. The causal relationship between energy and GNP: an international comparison. J. Energy Development 10, 249-272. 